\title{
МЕТОДОЛОГІЯ КОМПЕТЕНТНІСНОГО ПІДХОДУ ДО ПРОБЛЕМИ ПРОФЕСІЙНОЇ ПІДГОТОВКИ МАЙБУТНІХ ІНЖЕНЕРІВ ЗІ СПЕЦІАЛЬНОСТІ «ЕЛЕКТРОЕНЕРГЕТИКА, ЕЛЕКТРОТЕХНІКА ТА ЕЛЕКТРОМЕХАНІКА» В УМОВАХ МАСОВИХ ВІДКРИТИХ ДИСТАНЦИЙНИХ КУРСІВ
}

\section{Бацуровська I. В.}

\section{ВСТУП}

Сучасний інформаційний світ вимагає переосмислення підходів до отримання вищої освіти. Сьогодні інформаційні й телекомунікаційні технології $\epsilon$ галуззю науки i техніки, яка найбільш інтенсивно розвивається як за кордоном, так і в Україні. Динамічний розвиток телекомунікаційної інфраструктури, теоретико-методичне обгрунтування дидактичних можливостей дистанційного навчання, розвиток його програмної й методичної підтримки вможливлюють організацію такого навчального процесу, в якому максимально враховуються особливості, здібності й схильності кожного з тих, хто навчається, а також достатньою мірою забезпечується диференціація навчання. Світове співтовариство ввійшло в третє тисячоліття в умовах кардинальних зрушень, які охопили всі сфери людської діяльності. Цілком природно, що й Україна (як невід'ємний складник світової спільноти) зазнає відповідних змін і новацій. На межі тисячоліть, як зазначає В.Г. Кремень ${ }^{1}$, «відбувається історичний перехід людства від індустріальної до інформаційної цивілізації». Так, ми стаємо свідками створення глобального світопорядку, в умовах якого інформація, наука й освіта задають темпоритм саморозгортання та сталість функціонування нового типу соціальних відносин. Вища освіта перебуває на шляху вдосконалення за рахунок дистанційних технологій. Навчання супроводжується інтерактивними засобами та дистанційними курсами. Набуває розвитку масовість відкритих дистанційних курсів. Накопичений раніше методологічний потенціал виявився значною мірою вичерпаним, а освітня практика висунула такі завдання, які дуже складно вирішити в межах колишніх методологічних підходів ${ }^{2}$. Динаміка сучасного життя й нашого

${ }^{1}$ Кремень В.Г. Енциклопедія освіти. Київ : Юрінком Інтер. 2008. 466 с.

2 Вища освіта України і Болонський процес : навчальний посібник / Степко М.Ф., Болюбаш Я.Я., Шинкарук В.Д. та ін. ; за ред. В.Г. Кременя. Київ : Освіта. 2004. С. 184. 
дослідження вимагає подальшого вдосконалення методологічного аспекту масових відкритих дистанційних курсів для потреб освітньої практики. Електрична енергетика $\epsilon$ основою науково-технічного прогресу сьогодення, оскільки забезпечує людство теплом, світлом та енергією. Професійна підготовка майбутніх інженерів спеціальності «Електроенергетика, електротехніка та електромеханіка» здійснюється на основі досвіду в розробленні та функціонуванні систем енергоспоживання в промисловості, розробленні нових технологій приймання, передання та споживання електроенергії, вимог до енергозбереження, глобального інформаційного управління енергетикою споживання, чіткої перспективи розвитку нових джерел виробництва електроенергії та в підвищенні уваги до застосування енергозберігальних заходів у промисловості ${ }^{3}$. Професійна підготовка майбутніх інженерів базується на останніх розробках техніки i технології, особлива увага приділяється електрообладнанню машини та вивченню питань створення сучасної відновлюваної енергетики джерел, використання енергоефективних технологій. Здобувачі вищої освіти за цією спеціальністю займаються розробленням проектної та робочої документації енергосистем, розрахунком електричних ланцюгів та використанням обчислювального обладнання для проектних розрахунків, планування навантажень та споживання електроенергії. Вони контролюють роботу електрообладнання та автоматичних систем управління на електростанціях, дбають про обслуговування електростанцій та електромереж. Тому застосування компетентнісного підходу в професійній підготовці майбутніх інженерів спеціальності «Електроенергетика, електротехніка та електромеханіка» в умовах масових відкритих дистанційних курсів $\epsilon$ актуальним питанням сьогодення.

\section{1. Методологія як основа педагогічного дослідження}

Погоджуючись із думками А.Я. Баскакова та Н.В. Туленкова ${ }^{4}$, зазначимо, що методологія як учення про основи пізнання аналізує та оцінює філософські й світоглядні позиції, на які спирається дослідник у процесі наукового дослідження. Методологія як учення про способи та прийоми дослідження розглядає суттєві характеристики конкретних методів пізнання, що становлять загальний напрям дослідження. Значення методології полягає в тому, що вона дозволяє

${ }^{3}$ Oliynik V., Samoylenko O., Batsurovska I., Dotsenko N., Gorbenko O. Pedagogical model of preparation of future engineers in specialty "Electric Power, Electrical Engineering and Electrical Mechanics" with use of massive online courses. Information Technologies and Learning Tools. 2019. Vol 73, № 5. C. 161-173.

${ }^{4}$ Баскаков А.Я., Туленков Н.В. Методология научного исследования : учебное пособие. Киев : МАУП. 2004. 26 с. 
систематизувати весь обсяг наукового знання й створити умови для розроблення подальших ефективних напрямів дослідження. Головним завданням методології наукового пізнання $\epsilon$ синтез накопичених наукових знань, що дає змогу забезпечити використання досягнень розвитку науки в практичних цілях. Особливе місце в розробленні певних теорій методології дослідження належить Сократу, Платону й Аристотелю. Сократ поставив на перший план діалектичну природу мислення як спосіб здобуття істини в процесі зіставлення різних уявлень, понять, їх порівнянь, розподілу, визначення тощо. Знання про перехід від нечітких уявлень до подрібнених і чітких загальних понять розглядалося ним як метод удосконалення мистецтва життя 5 . Таким чином, логічні операції в Сократа підпорядковувались етичним цілям: предметом істинного знання має бути тільки те, що сприятливе для цілеспрямованої діяльності, мета ж визначається шляхом відповідно організованої роботи думки. Платон убачав зміст своєї діалектики понять і категорій у пошуку принципу кожної речі; для досягнення цього думка повинна рухатися відповідно до об'єктивної логіки предмета пізнання. Аристотель піддав аналізу принципи побудови суджень, правила узагальнень і доказів, питання визначення термінів, роль індукції й дедукції в досягненні істини. Йому належить важливе для методології розроблення вчення про категорії як форми організації пізнання, їх діалектику (співвідношення потенційного та актуального, форми і матерії тощо). Аристотель розглядав створену ним логічну систему як «органон» - універсальне знаряддя істинного пізнання.

Якщо раніше поняття «методологія» охоплювало переважно сукупність уявлень про філософські основи науково-пізнавальної діяльності, то тепер йому відповідає внутрішньо диференційована і спеціалізована сфера знання 6 . Від теорії пізнання, яка досліджує процес пізнавальної діяльності в цілому і його змістові основи зокрема, методологію відрізняє акцент на методах, шляхах досягнення істинного й практичного ефективного знання. Від наукознавства методологія відрізняється своєю спрямованістю на внутрішні механізми, логіку руху й організацію знання ${ }^{7}$. У філософському енциклопедичному словнику ${ }^{8}$ термін «методологія» визначається як система принципів і способів організації й побудови теоретичної та практичної діяльності,

\footnotetext{
${ }^{5}$ Максимюк С.П. Педагогіка : навчальний посібник. Київ : Кондор. 2009. 134 с.

${ }^{6}$ Основні напрями реформування вітчизняної педагогічної освіти. Наука і вища освіта в Україні : міра взаємодії. Київ. 2008. С. 19-20.

7 Білодід I.К. Словник української мови в 11 томах АН УРСР. Інститут мовознавства. Київ : Наукова думка. 1980. URL: http://ukrlit.org/slovnyk/slovnyk_ukrainskoi_movy_v_11_tomakh. (дата звернення: 11.07.18).

${ }^{8}$ Ильичев Л.Ф., Федосеев П.Н. Философский энциклопедический словарь. Москва : Сов. энцикл. 1983. 365 с.
} 
а також як учення про цю систему. У своїх дослідженнях Р.В. Войтович ${ }^{9}$ надає такі визначення методології:

- система наукових принципів, на яких базується дослідження і здійснюється вибір сукупності пізнавальних засобів, методів, прийомів дослідження;

- учення про науковий метод пізнання або систему наукових принципів, на основі яких будується дослідження;

- теорія методів дослідження, створення концепцій як системи знань про теорію науки або систему методів дослідження;

- загальна форма організації наукового знання (науковопізнавальної діяльності), що містить у собі принципи його побудови.

Учені виокремлюють такі варіанти структурного розуміння методології в сучасній науці:

1) методологія - це деяка сукупність філософських методів пізнання, що охоплює індуктивний, раціоналістичний, діалектичний, феноменологічний, системний методи. Методологія в такому разі зводиться до вершин філософської методології, 3 неї виключається величезний пласт конкретних методів і прийомів ${ }^{10}$;

2) методологія розглядається як система методів пізнання, зокрема конкретних. У цьому разі вона представляється у вигляді деякого арсеналу методів діяльності. Недоліком такого підходу $\epsilon$ те, що методологія звужується до розуміння тільки методів пізнання, при цьому обмежується методологічна роль принципів, теорій і парадигм ${ }^{11}$;

3) методологія розуміється як загальна теорія методів пізнання. Вона частково збігається 3 теорією пізнання й одночасно виявляється ширшою за гносеологію, оскільки іiі цікавлять не тільки методи пізнання, а й методи інших форм людської діяльності ${ }^{12}$;

4) методологія зводиться до сукупності принципів діяльності, які $€$ способом регуляції останньої, що є досить переконливим, однак виникає заперечення стосовно обмеження методології лише одним складником - принципами ${ }^{13}$.

5) методологія $є$ специфічною діяльнісною системою, яка вміщує принципи, категорії, теорії, парадигми і методи, що мають специфічне

9 Войтович Р.В. Логіка, методологія і методика наукових досліджень : навчальний посібник Київ : ЦНЛ. 2005. С. 5.

10 Фіцула М.М. Педагогіка: навчальний посібник. Київ : Видавничий центр «Академія». 2001. С. 246.

11 Крушельницька О.В. Методологія та організація наукових досліджень : навчальний посібник. Київ : Кондор. 2003. С. 54.

12 Дубасенюк О.А., Вознюк О.В. Професійно-педагогічні задачі: типологія та технологія розв'язання : навчальний посібник. Житомир : Вид-во ЖДУ ім. І. Франка. 2010.

13 Ярощук Л.Г. Основи педагогічних вимірювань та моніторингу якості освіти : навчальний посібник. Луцьк. 2010. С. 102. 
цільове призначення, пов'язане 3 реалізацією діяльності. Вона $\epsilon$ способом діяльності, організації діяльнісної системи. Цей підхід заслуговує на увагу, оскільки він інтегрує всі основні складники методології ${ }^{14}$

6) методологія розглядається як деяка система, що об'єднує відповідно до основних видів діяльності методологію пізнання, оцінки й практичної діяльності. Такий підхід дає змогу широко трактувати методологію в аспекті діяльності загалом, але він залишає відкритим питання про структуру кожного діяльнісного різновиду методології ${ }^{15}$;

7) методологія розглядається як багаторівнева споруда, на верхніх поверхах якої розміщується філософська методологія, далі загальнонаукова, а на найнижчих - методологія галузевих видів науки. Зазначимо, що ця ієрархія має системний характер, оскільки всі іiі поверхи утворюють цілісний методологічний організм. При цьому галузеву методологію мають постійно підтримувати філософська $\mathrm{i}$ загальнонаукова ${ }^{16}$;

8) методологія зводиться до мети, змісту і методів дослідження. Із таким підходом важко погодитися, оскільки в цьому разі методологія зводиться до концептуального викладу не всіх складників. Не $\epsilon$ виправданим також ототожнення фундаментальної й філософської методології ${ }^{17}$.

О.Ю. Оболенський висловлює точку зору про те, що методологія наукове узагальнення принципів побудови методів, тобто система, яка реалізуе три функції: одержання, створення нового знання, структурування цього знання у вигляді нових понять, категорій, законів; організація використання нових знань у суспільно-практичній діяльності ${ }^{18}$. У нашому дослідженні методологію будемо розглядати із системно-діяльнісних позицій, відповідно до яких вона досліджує взаємозумовленість, взаємозв'язок і залежність систем знань і систем діяльності. По суті, вона $\epsilon$ самостійною регулятивно-діяльнісною системою, способом наукової діяльності, вченням про структуру, логічну організацію й засоби діяльності, що визначають шлях

14 Шейко В.M, Кушнаренко Н.М. Організація та методика науководослідницької діяльності : підручник. Київ : Знання. 2004. С. 53.

${ }^{15}$ Бакуменко В., Князєв В., Сурмін Ю. Методологія державного управління: проблеми становлення та подальшого розвитку. Вісник УАДУ. № 2. 2003. С. 11-12.

16 Кушнір В.А. Системний аналіз педагогічного процесу: методологічний аспект. Кіровоград : КДПУ. 2001. С. 311.

17 Пєхота О.М. Освітні технології : навчально-методичний посібник. Київ : A.C.K. 2002. С. 56.

18 Оболенський О.Ю. Державне управління та державна служба : словникдовідник. Київ : КНЕУ. 2005. С. 130 
досягнення цілі. Погоджуємося із С.С. Вітвицькою ${ }^{19}$, котра зазначає, що тлумачення методології характеризується як сукупність способів дослідження, вчення про методи наукового пізнання. Адже термін «методологія» (грецького походження) перекладається як «теорія методів». I хоч сучасна наука не зводить його лише до такого розуміння, проте вчення про методи $\epsilon$ важливим складником методології. Він визначає їх місце та пізнавальні можливості в загальній системі наукового пошуку, основи конструювання логіки дослідження. Саме в методах методологічні положення та принципи набувають свого дієвого й інструментального вираження. Заслуговують на увагу думки Г.С. Цехмістрової ${ }^{20}$ М.П. Олійника та С.У. Гончаренка ${ }^{21}$, котрі розглядають методологію як учення про метод пізнання або як систему наукових принципів і способів побудови теоретичної й практичної діяльності, а також як учення про цю систему. Вони наголошують, що в загальній системі методологічного знання необхідно враховувати кілька рівнів методології. Змістом першого рівня $\epsilon$ філософське знання. Другий рівень становить загальнонаукову методологію (системний i діяльнісний підходи, характеристика різних типів наукових досліджень, їх етапи й елементи: гіпотеза, об’єкт і предмет дослідження, мета, завдання тощо). Третій рівень становить конкретна наукова методологія, тобто сукупність методів, принципів дослідження і процедур, які застосовують у тій чи іншій спеціальній науковій дисципліні. Деякі вчені виділяють четвертий рівень методології, який утворюють методика й техніка дослідження. Так, Е.Г. Юдін ${ }^{22}$ у структурі методологічного знання виділяе чотири рівні: філософський, загальнонауковий, конкретнонауковий i технологічний. Дослідники М.А. Данилов та Н.I. Болдирєв ${ }^{23}$ розрізняють три види методології: часткову сукупність методів кожної конкретної науки; загальну - сукупність більш загальних методів (методи педагогіки є водночас іiі методами i методами загальної методології для часткових дидактик); філософську - систему діалектичних методів, які $є$ найзагальнішими і діють на всьому полі наукового пізнання, конкретизуючись i через

19 Вітвицька С.С. Основи педагогіки вищої школи: підручник за модульнорейтинговою системою навчання для студентів магістратури. Київ : Центр навчальної літератури. 2006. С. 27-28.

${ }^{20}$ Цехмістрова Г.С. Основи наукових досліджень : навчальний посібник. Київ : Видавничий Дім «Слово». 2003. С. 187.

${ }^{21}$ Гончаренко С.У., Олійник М.П. Методика навчання і наукових досліджень у вищій школі: навчальний посібник. Київ : Вища школа. 2003. С. 298.

22 Юдин Э.Г. Системный подход и принцип деятельности: методолог. проблемы современной науки. Москва : Наука. 1978. С. 31.

${ }_{23}$ Данилов М.А., Болдырев Н.И. Проблемы методологии педагогики и методики исследований : монография. Москва : Педагогика. 1971. С. 53. 
загальнонаукову, i через часткову методологію. Учений-педагог M.M. Фіцула ${ }^{24}$, розглядаючи методологію педагогіки, висвітлює іï як багаторівневу систему, яку утворюють:

- філософська методологія, що виражає світоглядну інтерпретацію результатів наукової діяльності, форм і методів наукового мислення у відображенні картини світу;

- загальнонаукові принципи, форми, підходи до відображення дійсності (системний підхід, моделювання, статистична картина світу тощо);

- конкретнонаукова методологія (сукупність методів, форм, принципів дослідження в конкретній науці);

- дисциплінарна методологія, що стосується частини науки (дидактика);

- методологія міждисциплінарних досліджень.

\section{2. Компетентнісний підхід у професійній підготовці майбутніх інженерів спеціальності}

\section{«Електроенергетика, електротехніка та електромеханіка»}

Загальнонаукові niдxоди до відображення дійсності становлять другий рівень методології дослідження професійної підготовки майбутніх інженерів. Загальнонаукова методологія використовується в більшості наук, оскільки будь-яке наукове відкриття має не лише предметний, але й методологічний зміст. Воно спричиняє критичний перегляд прийнятого понятійного апарату, чинників, передумов i підходів до інтерпретації матеріалу, що вивчається. Науковий підхід особливий спосіб мислення та пізнання об'єктивної реальності, що формується умовами дослідження, високим рівнем знань і професійної підготовки та цілісним спрямуванням. Сутність дефініції «підхід» у тлумачному словнику ${ }^{25}$ представлено як сукупність способів, прийомів розгляду чого-небудь, впливу на кого-, що-небудь, ставлення до кого-, чого-небудь. Однією 3 найважливіших особливостей професійної підготовки майбутнього інженера $є$ зростання значення його компетентності. Дослідник I.I. Драч ${ }^{26}$ під компетентністю розуміє спеціальну здатність людини, необхідну для виконання конкретної дії

${ }^{24}$ Фіцула М.М.. Педагогіка : навчальний посібник. Київ : Видавничий центр «Академія». 2001. С. 30.

${ }^{25}$ Великий тлумачний словник сучасної української мови. Уклад. і голов. ред. В.Т. Бусел. Київ : Ірпінь: ВТФ «Перун». 2009.

26 Драч I.I. Компетентнісний підхід як ключовий методологічний інструмент підготовки майбутніх викладачів вищої школи. Теорія та методика управління освітою : електронне наукове фахове видання. ДВНЗ «Університет менеджменту освіти» АПН України. 2011. № 7. URL: http://tme.umo.edu.ua/ (дата звернення: 11.05.2015. 
в конкретній предметній галузі, що включає вузькоспеціальні знання, навички, способи мислення і готовність нести відповідальність за свої дії. На думку дослідника В.В. Химинця ${ }^{27}$, компетентність - це системна єдність, що інтегрує особистісні, предметні й інструментальні особливості та засоби. Дослідник уважає, що компетентність - це не просто володіння знаннями, а постійне прагнення до їх оновлення та використання в конкретних умовах, тобто володіння оперативними й мобільними знаннями; це гнучкість i критичність мислення, що припускає здатність вибирати найбільш оптимальні та ефективні рішення і відкидати помилкові. У своїх працях закордонні вчені Дж. Равен ${ }^{28}$, К. Крістенсен ${ }^{29}$ та Д. Корнер ${ }^{30}$ зазначають, що компетентність характеризує суб'єкта діяльності й означає володіння відповідними знаннями та здібностями, що дозволяють людині обгрунтовано судити про певну сферу діяльності й ефективно в ній діяти. Погоджуючись із думкою вітчизняних учених, зокрема В.Г. Кременя ${ }^{31}$, I.I. Драча ${ }^{32}$, Г.В. Кашкарьова ${ }^{33}$, зазначимо, що компетентність, яка спрямована на професійну діяльність, є здатністю застосовувати свої знання та вміння в науковій і дослідницькій практиці, використовуючи при цьому всі свої розумові, психологічні й навіть фізичні можливості. Вона включає такі складники:

- уміння оцінювати результати своєї освітньої та наукової праці, здатність самостійного набуття нових знань і вмінь;

- спеціальну компетентність - підготовленість до самостійного виконання професійно-виробничих завдань;

27 Химинець В. В. Компетентнісний підхід до професійного розвитку вчителя. Закарпатський інститут післядипломної педагогічної освіти. URL: http://zakinppo.org.ua/2010-01-18-13-44-15/233-2010-08-25-07-10-49 (дата звернення: 23.11.2012).

28 Равен Дж. Педагогическое тестирование: проблемы, заблуждения, перспективы. Пер. с англ. Москва : Когито-Центр. 1999. С. 37.

${ }^{29}$ Christensen C. The innovator's solution: creating and sustaining successful growth. Harvard Business Press. 2003.

30 Cormier Dave. The CCK08: MOOC Connectivism course, 1/4 way. URL: http://davecormier.com/edblog/2008/10/02/the-cck08-mooc-connectivismcourse14-way (Last accessed 02.10.2010)

31 Вища освіта України і Болонський процес : навчальний посібник. Степко М.Ф., Болюбаш Я.Я., Шинкарук В.Д. та ін. ; за ред. В.Г. Кременя. Київ : Освіта. 2004. С. 144 .

32 Драч I.I. Компетентнісний підхід як ключовий методологічний інструмент підготовки майбутніх викладачів вищої школи. Теорія та методика управління освітою : електронне наукове фахове видання. 2011. № 7. URL: http://tme.umo.edu.ua/ (дата звернення: 11.05.2015).

${ }^{33}$ Кашкарьов Г.В. Теоретичні та практичні аспекти компетентнісного підходу до підготовки вчителів правознавства : монографія. Донецьк : Ландон-XXI. 2011. С. 113. 
- соціальну компетентність - здатність до групової та колективної діяльності й співпраці з іншими працівниками, готовність взяти на себе відповідальність за результати праці ${ }^{34}$.

У своїй монографії О.А. Дубасенюк ${ }^{35}$ зазначає, що компетентність $€$ властивістю особистості, яка забезпечує високий рівень саморозвитку та наукового самовдосконалення. А отже, компетентність здобувача вищої освіти $є$ властивістю його особистості, що забезпечує високий рівень саморозвитку та наукового самовдосконалення в науці й освіті.

У контексті здійснення наукового пошуку за відповідним напрямом дослідження компетентність $€$ засобом пристосування до наукового середовища, оскільки наука й освіта творять людину відповідно до свого образу та подоби, визначаючи її інтереси, переконання, смаки, прагнення, бажання; формують загальні інтереси, подібності в індивідів, що займаються однією справою ${ }^{36}$. Г.В. Кашкарьов ${ }^{37}$ визначає компетентність фахівця як систематизовану сукупність знань, високих моральних норм i професійного кодексу. У межах професійної стратифікації суспільства компетентність можна розглядати як професійне покликання науковця, професійний обов'язок, що формується в єдності стилю життя, професії та освіти. Згідно 3 позиціями А.В. Хуторського ${ }^{38}$, компетентність - це якість фахівця, яка допомагає йому ефективно виконувати практичні завдання стосовно власної соціалізації, сприяє забезпеченню внутрішніх умов діяльнісної інтеграції особистості фахівця в суспільство за рахунок розвитку ціннісних орієнтацій, формування практичних умінь діяльнісної соціально бажаної самореалізації.

Компетентність майбутнього електроенергетика можна трактувати як підготовленість і здатність суб'єкта праці до виконання завдань й обов'язків на посаді, а також як ставлення до успішної професійної

34 Бацуровська I.В., Самойленко О.М., Андрющенко Я.Е. Компетентнісно орієнтоване середовище як засіб підготовки здобувача вищої освіти. Матеріали причорноморської регіональної науково-практичної конференції професорськовикладацького складу «Розвиток українського села - основа аграрної реформи України» 25-27 квітня 2018 р. Миколаїв : МНАУ. 2018. С. 43-48.

35 Дубасенюк О.А. Професійна педагогічна освіта: компетентнісний підхід : монографія. Житомир, Житомир. держ. ун-т ім. І. Франка. 2011. С. 302.

36 Бацуровська I.В., Самойленко О.М., Ручинська Н.С. Методика реалізації компетентнісного підходу до навчання здобувачів вищої освіти в умовах єдиного інформаційно-освітнього середовища. Від знаннєвої парадигми до компетентнісної: реалії, перспективи : матеріали всеукраїнської науково-практичної конференції 3 міжнародною участю. Херсон : КВНЗ «Херсонська академія неперервної освіти». 2017. С. $188-192$.

37 Кашкарьов Г.В. Теоретичні та практичні аспекти компетентнісного підходу до підготовки вчителів правознавства : монографія. Донецьк : Ландон-ХXI. 2011. С. 134.

${ }^{38}$ Хуторской А.В. Ключевые компетенции и образовательные стандарты. URL: http://www.eidos.ru/journal/2002/0423.htm (дата звернення: 23.11.2012). 
діяльності, усвідомлення іiі значення і певних специфічних завдань у сукупності з усіма знаннями і навичками, що використовуються під час іiі здійснення. Компетентність у сфері науки можна трактувати як інтеграцію накопиченого досвіду й отриманих знань, що дозволяють людині швидко вирішувати поставлені завдання в дослідницькій та науковій діяльності. Автори монографії О.А. Дубасенюк, Т.В. Семенюк та О.Є. Антонова ${ }^{39}$ зазначають, що компетентність $\epsilon$ складним утворенням. До іiі основних елементів вони зараховують такі складники, як компетентність у галузі фахових предметів; соціальнопсихологічна компетентність у галузі процесів спілкування; диференціально-психологічна компетентність у сфері мотивації, здібностей та спрямованості; аутопсихологічна компетентність у сфері переваг і недоліків власної діяльності та особистості, оскільки зріла сформована особистість - професійна необхідність. Виходячи з поняття компетентнісного підходу, А.В. Хуторський ${ }^{40}$ зазначає, що компетентнісний підхід $€$ одним зі способів реалізації концепцій розвивальної та особистісно зорієнтованої освіти. На думку вченого, такий підхід базується на засобах змісту освіти, в основу якого покладено такі компоненти, як знання, вміння, досвід творчої діяльності, досвід реалізації емоційно-ціннісних ставлень.

Поняття «компетентнісний підхід» можна розуміти як спрямованість освітнього процесу на формування та розвиток ключових i предметних компетентностей особистості. Компетентнісний підхід скеровує освітній процес на формування цілого набору компетентностей, які мають опанувати здобувачі вищої освіти під час навчання. При цьому традиційна система освіти акцентувала основні зусилля на набутті знань, умінь i навичок, що догматично абсолютизувало знання і сформувало знаннєвий підхід до професійної підготовки здобувачів вищої освіти. Базуючись на позиціях законодавства про інтелектуальну діяльність ${ }^{41}$ та відповідно до Концепції організації підготовки ${ }^{42}$, компетентнісний підхід ставить на перше місце не поінформованість здобувача вищої освіти, а вміння розв'язувати наукові проблеми, що виникають у пізнавальній, технологічній й освітній діяльності, у сферах етичних, соціальних,

39 Дубасенюк О.А., Семенюк Т.В., Антонова О.С. Професійна підготовка майбутнього вчителя до педагогічної діяльності : монографія. Житомир : Житомир. держ. пед. ун-т. 2003. С. 53.

40 Хуторской А.В.. Концепция Научной школы человекосообразного образования : научное издание. Москва : Издательство «Эйдос». 2015

41 Законодавство про інтелектуальну діяльність : збірник нормативних актів. 2000. Київ : Юрінком Інтер.

42 Про Концепцію організації підготовки магістрів в Україні : наказ МОН № 99 від 10.02.2010 p. URL: http://osvita.ua/legislation/Vishya_osvita/7094/ (дата звернення 29.01.2016). 
правових, професійних, особистих взаємовідносин. Зважаючи на це, зазначений підхід передбачає такий вид змісту освіти, який не зводиться до знаннєво орієнтованого компонента, а передбачає цілісний обмін досвідом вирішення професійних проблем, виконання ключових функцій, соціальних ролей, компетенцій. Реалізація компетентнісного підходу здійснюватиметься за рахунок оновлення навчально-методичного забезпечення освітнього процесу здобувачів вищої освіти, тобто створення сучасного електронного контенту, єдиної системи освітнього процесу, наукової діяльності та обміну досвідом на світовому рівні тощо. Важливим фактором щодо реалізації окресленого підходу за рахунок оновлення навчально-методичного забезпечення є функції, які виконують сучасні комп’ютерно-планшетні засоби. Компетентнісний підхід щодо професійної підготовки майбутніх інженерів в умовах масових відкритих дистанційних курсів реалізується за рахунок сучасних навчальних засобів, які виконують інформаційну, мотиваційну i розвивальну функції. Реалізація компетентнісного підходу в професійній підготовці майбутніх інженерів у галузі електричної інженерії буде успішною за умови забезпечення всіх складників навчального процесу, а саме: чіткого визначення цілей навчання, добору відповідного змісту навчання, оновлення навчально-методичного забезпечення, добору ефективних методів, прийомів навчання й форм організації майбутньої діяльності, відповідної професійної підготовки. Відповідно до компетентнісного підходу до організації професійної підготовки здобувачів вищої освіти, абсолютною цінністю є невідчужені від особистості знання, а сама людина розглядається «через призму особистості того, кого навчають, зокрема ії потреб, мотивів, здібностей, активності, інтелекту та інших особливостей» ${ }^{43}$. Такий підхід представляє дослідницький підхід і принцип організації практики підготовки фахівця, що розглядає об'єкт дослідження, практику з позицій цілісності та системності.

Увесь процес професійної підготовки майбутніх інженерів в умовах масових відкритих дистанційних курсів побудовано згідно 3 компетентнісним підходом, спрямовано на формування потреб здобувачів вищої освіти в навчанні, їх зацікавленості в одержанні знань. Компетентнісний підхід (у якому реалізується ціннісна функція процесу підготовки) дає можливість, з одного боку, вивчати явища 3 погляду закладених у них можливостей задоволення потреб людей, з іншого - виконувати завдання гуманізації суспільства. Ціннісну функцію навчання підкреслюе i перевага діалогічної форми спілкування, яка є основною під час дидактичного процесу та сприяє

43 Галімов Ю.А. Комплексний підхід до забезпечення якості підготовки фахівців. Вісник Національної академії Державної прикордонної служби Украӥни. 2011. URL: www.irbis-nbuv.gov.ua/ (дата звернення 09.04.2018). 
вільному обміну думками i враженнями, стимулює різні форми пізнавальної активності на занятті, розвиває навички співробітництва під час спільної діяльності, комунікативні вміння, соціальний досвід ${ }^{44}$. Такий підхід до організації навчально-виховного процесу забезпечує сприятливу морально-психологічну атмосферу на занятті, реалізацію позитивного емоційного навчання, створення такого навчальнометодичного забезпечення занять, яке б допомогло слухачеві уникнути фізичних перевантажень та психологічного дискомфорту. Компетентнісний підхід до професійної підготовки майбутніх фахівців у галузі електричної інженерії в умовах масових відкритих дистанційних курсів має забезпечувати розвиток i саморозвиток особистості здобувача вищої освіти, виходячи 3 виявлених індивідуальних особливостей. Відомий американський психолог Дж. Брунер ${ }^{45}$ наголошує, що «<...> у будь-якій дисципліні немає нічого суттєвішого, ніж властиві ій спосіб мислення. У іiі викладанні найважливішим $\epsilon$ дати людині змогу якомога раніше засвоїти потрібний спосіб мислення, фіксуючи підхід до фактів, форми зв'язку між ними». Реалізація компетентнісного підходу базується на детермінованому системному аналізі параметрів у розширеному діагностичному просторі масового відкритого дистанційного курсу, методиках прогнозування динаміки деградації; на автоматизованих індикативних засобах оперативного інформування здобувачів вищої освіти в межах єдиного освітнього простору про результати діагностування та наданні їм конкретних методичних рекомендацій для уникнення освітніх прогалин у процесі професійної підготовки. Реалізація компетентнісного підходу будується на організації професійної підготовки за рахунок абсолютної цінності людини, яка розглядається через призму особистості, ії потреб, мотивів, здібностей, активності, інтелекту та інших особливостей. Зазначений підхід здійснюється 3 погляду закладених можливостей задоволення потреб роботодавця та вирішення завдань гуманізації суспільства, співробітництва під час спільної діяльності; комунікативних умінь та соціального світового досвіду, переходу від орієнтації на усередненого фахівця до варіативності програм професійної підготовки майбутнього інженера, переходу від статистичної моделі знань до процесу розумового розвитку, до динамічних структурованих систем розумових дій. У процесі реалізації цього підходу відбувається диференційована

44 Лапінський В.В., Пилипчук А.Ю., Шишкіна М.П. Засоби інформаційнокомунікаційних технологій єдиного інформаційного простору системи освіти України : монографія. Київ : Педагогічна думка. 2010.

45 Івашкевич Е.3. Комплексний підхід до визначення структури соціального інтелекту педагога. Проблеми сучасної психологї. 2016. Вип. 34. URL: ttp://problemps.kpnu.edu.ua/en/ (дата звернення: 04.04.2018). 
організація навчальної діяльності, що враховує особливості когнітивної сфери особистості здобувачів вищої освіти, психологічні та індивідуальні запити, можливості й інтереси в конкретній сфері.

\section{ВИСНОВКИ}

Компетентнісний підхід щодо підготовки майбутніх інженерів спеціальності «Електроенергетика, електротехніка та електромеханіка» в умовах масових відкритих дистанційних курсів зміщує акценти 3 процесу накопичення нормативно визначених знань, умінь і навичок до площини формування й розвитку здатності практично діяти у сфері науки i творчо застосовувати набутий освітній досвід у різних ситуаціях. Змінюється й модель поведінки майбутнього інженера, переміщуючись від пасивного засвоєння знань до дослідницькоактивної, самостійної та самоосвітньої діяльності. Процес учіння наповнюється розвивальною функцією, яка стає інтегрованою характеристикою навчання. Така характеристика має сформуватися в процесі навчання і містити знання, вміння, навички, ставлення, досвід діяльності й поведінкові моделі особистості. Компетентнісний підхід до організації професійної підготовки майбутніх інженерів в умовах масових відкритих дистанційних курсів орієнтує педагогічний процес на продуктивний розвиток здобувача вищої освіти, розширення можливостей формування його особистості, адаптації в сучасному динамічному суспільстві, дає можливість сприймати його як цілісну й унікальну особистість, закласти основи стратегії досягнення вершин індивідуального розвитку особистості в інтелектуально-пізнавальній, емоційній, професійній сферах. Продуктом такої організації процесу навчання $є$ розвинена особистість, підготовлена до універсальної фахової діяльності.

\section{АНОТАЦІЯ}

Представлено методологію компетентнісного підходу до проблеми професійної підготовки майбутніх інженерів спеціальності «Електроенергетика, електротехніка та електромеханіка» в умовах масових відкритих дистанційних курсів. Проведено аналіз поняття методології. У нашому дослідженні методологію будемо розглядати із системно-діяльнісних позицій, відповідно до яких вона досліджує взаємозумовленість, взаємозв'язок і залежність систем знань і систем діяльності. По суті, вона $\epsilon$ самостійною регулятивно-діяльнісною системою, способом наукової діяльності, вченням про структуру, логічну організацію і засоби діяльності, що визначають шлях досягнення цілі. Розглянуто особливості компетентнісного підходу в професійній підготовці майбутніх інженерів спеціальності «Електроенергетика, електротехніка та електромеханіка». Реалізація компетентнісного підходу здійснюватиметься за рахунок оновлення навчально-методичного 
забезпечення освітнього процесу майбутніх інженерів, тобто створення сучасного електронного контенту, єдиної системи освітнього процесу, наукової діяльності та обміну досвідом на світовому рівні тощо. Важливим фактором щодо реалізації зазначеного підходу за рахунок оновлення навчально-методичного забезпечення $\epsilon$ функції, які виконують сучасні комп'ютерно-планшетні засоби. Реалізація компетентнісного підходу в професійній підготовці майбутніх інженерів буде успішною за умови забезпечення всіх складників навчального процесу, а саме: чіткого визначення цілей навчання, добору відповідного змісту навчання, оновлення навчально-методичного забезпечення, добору ефективних методів, прийомів навчання, форм організації професійної діяльності, відповідної професійної підготовки. Компетентнісний підхід здійснюється 3 погляду закладених можливостей задоволення потреб роботодавця, співробітництва під час спільної діяльності, комунікативних умінь та соціального світового досвіду, переходу від орієнтації на усередненого фахівця до варіативності програм професійної підготовки майбутнього інженера.

\section{ЛІТЕРАТУРА}

1. Кремень В.Г. Енциклопедія освіти. Київ : Юрінком Інтер. 2008. $466 \mathrm{c}$.

2. Вища освіта України і Болонський процес : навчальний посібник / Степко М.Ф., Болюбаш Я.Я., Шинкарук В.Д. та ін. ; за ред. В.Г. Кременя. Київ : Освіта. 2004. 184 с.

3. Oliynik V., Samoylenko O., Batsurovska I., Dotsenko N., Gorbenko O. Pedagogical model of preparation of future engineers in specialty 'Electric Power, Electrical Engineering and Electrical Mechanics' with use of massive online courses. Information Technologies and Learning Tools. 2019. Vol 73, № 5. C. 161-173.

4. Баскаков А.Я., Туленков Н.В. Методология научного исследования: учебное пособие. Киев : МАУП. 2004. 26 с.

5. Максимюк С.П. Педагогіка : навчальний посібник. Київ : Кондор. 2009. 134 с.

6. Основні напрями реформування вітчизняної педагогічної освіти. Наука і вища освіта в Україні : міра взаємодії. Київ. 2008. С. 19-20.

7. Білодід І.К. Словник української мови в 11 томах АН УРСР. Інститут мовознавства. Київ : Наукова думка. 1980. URL: http://ukrlit.org/slovnyk/slovnyk_ukrainskoi_movy_v_11_tomakh. (дата звернення 11.07.2018).

8. Ильичев Л.Ф., Федосеев П.Н. Философский энциклопедический словарь. Москва : Сов. энцикл. 1983. 365 с.

9. Войтович Р.В. 2005. Логіка, методологія і методика наукових досліджень : навчальний посібник. Київ : ЦНЛ. С. 5. 
10. Фіцула М.М. Педагогіка : навчальний посібник. Київ : Видавничий центр «Академія». 2001. 246 с.

11. Крушельницька О.В. Методологія та організація наукових досліджень : навчальний посібник. Київ : Кондор. 2003. 54 с.

12. Дубасенюк О.А., Вознюк О.В. Професійно-педагогічні задачі: типологія та технологія розв'язання : навчальний посібник. Житомир : Вид-во ЖДУ ім. І. Франка. 2010.

13. Ярощук Л.Г. Основи педагогічних вимірювань та моніторингу якості освіти : навчальний посібник. Луцьк. 2010. 102 с.

14. Шейко В.M, Кушнаренко Н.М. Організація та методика науководослідницької діяльності: підручник. Київ : Знання. 2004. С. 53.

15. Бакуменко В., Князєв В., Сурмін Ю. Методологія державного управління: проблеми становлення та подальшого розвитку. Вісник УАДУ. № 2. 2003. С. 11-12.

16. Кушнір В.А. Системний аналіз педагогічного процесу: методологічний аспект. Кіровоград : КДПУ. 2001. 311 с.

17. Пєхота О.М. Освітні технології : навчально-методичний посібник. Київ : А.С.К. 2002. С. 56.

18. Оболенський О.Ю. Державне управління та державна служба: словник-довідник. Київ : КНЕУ. 2005. 130 с.

19. Витвицька С.С. Основи педагогіки вищої школи : підручник за модульно-рейтинговою системою навчання для студентів магістратури. Київ: Центр навчальної літератури. 2006. С. 27-28.

20. Цехмістрова Г.С. Основи наукових досліджень : навчальний посібник. Київ : Видавничий Дім «Слово». 2003. С. 187.

21. Гончаренко С.У., Олійник М.П. Методика навчання і наукових досліджень у вищій школі : навчальний посібник. Київ : Вища школа. 2003. C. 298.

22. Юдин Э.Г. Системный подход и принцип деятельности: методолог. проблемы современной науки. Москва : Наука. 1978. 31 с.

23. Данилов М.А., Болдырев Н.И. Проблемы методологии педагогики и методики исследований : монография. Москва : Педагогика. 1971. С. 53.

24. Фіцула М.М. Педагогіка : навчальний посібник. Київ : Видавничий центр «Академія». 2001. С. 30.

25. Великий тлумачний словник сучасної української мови / Уклад. І голов. ред. В.Т. Бусел. Київ : Ірпінь: ВТФ «Перун». 2009.

26. Драч I.I. Компетентнісний підхід як ключовий методологічний інструмент підготовки майбутніх викладачів вищої школи. Теорія та методика управління освітою : електронне наукове фахове видання. ДВНЗ «Університет менеджменту освіти» АПН України. 2011. № 7. URL: http://tme.umo.edu.ua/ (дата звернення: 11.05.2015).

27. Химинець В.В. Компетентнісний підхід до професійного розвитку вчителя. Закарпатський інститут післядипломної педагогічної 
освіти. URL: http://zakinppo.org.ua/2010-01-18-13-44-15/233-2010-08-2507-10-49 (дата звернення 23.11.2012).

28. Равен Дж. Педагогическое тестирование: проблемы, заблуждения, перспективы. Пер. с англ. Москва: Когито-Центр. $1999.37 \mathrm{c}$.

29. Christensen C. The innovator's solution: creating and sustaining successful growth. Harvard Business Press. 2003.

30. Cormier Dave. The CCK08: MOOC Connectivism course, 1/4 way. URL: http://davecormier.com/edblog/2008/10/02/the-cck08-moocconnectivismcourse-14-way (last accessed 02.10.2010).

31. Вища освіта України i Болонський процес : навчальний посібник. Степко М.Ф., Болюбаш Я.Я., Шинкарук В.Д. та ін. ; за ред. В.Г. Кременя. Київ : Освіта. 2004. 144 с.

32. Драч I.I. Компетентнісний підхід як ключовий методологічний інструмент підготовки майбутніх викладачів вищої школи. Теорія ma методика управління освітою : електронне наукове фахове видання. 2011. № 7. URL: http://tme.umo.edu.ua/ (дата звернення: 11.05.2015).

33. Кашкарьов Г.В. Теоретичні та практичні аспекти компетентнісного підходу до підготовки вчителів правознавства : монографія. Донецьк : Ландон-XXI. 2011. 113 с.

34. Бацуровська I.B., Самойленко О.М., Андрющенко Я.Е. Компетентнісно орієнтоване середовище як засіб підготовки здобувача вищої освіти. Матеріали причорноморської регіональної науковопрактичної конференції професорсько-викладацького складу «Розвиток українського села - основа аграрної реформи України» 25-27 квітня 2018 р. Миколаїв: МНАУ. 2018. С. 43-48.

35. Дубасенюк О. А. Професійна педагогічна освіта: компетентнісний підхід : монографія. Житомир, Житомир. держ. ун-т ім. І. Франка. 2011. 302 с.

36. Бацуровська I.B., Самойленко О.М., Ручинська Н.С. Методика реалізації компетентнісного підходу до навчання здобувачів вищої освіти в умовах єдиного інформаційно-освітнього середовища. Вid знаннєвої парадигми до компетентнісної: реалії, перспективи : матеріали всеукраїнської науково-практичної конференції 3 міжнародною участю. Херсон : КВНЗ «Херсонська академія неперервної освіти». 2017. С. 188-192.

37. Кашкарьов Г.В. Теоретичні та практичні аспекти компетентнісного підходу до підготовки вчителів правознавства : монографія. Донецьк : Ландон-XXI. 2011. С. 134.

38. Хуторской А.В. Ключевые компетенции и образовательные стандарты. URL: http://www.eidos.ru/journal/2002/0423.htm (дата звернення: 23.11.2012). 
39. Дубасенюк О.А., Семенюк Т.В., Антонова О.С. Професійна підготовка майбутнього вчителя до педагогічної діяльності : монографія. Житомир : Житомир. держ. пед. ун-т. 2003. С. 53

40. Хуторской А.В.. Концепция Научной школы человекосообразного образования : научное издание. Москва : Издательство «Эйдос». 2015

41.Законодавство про інтелектуальну діяльність : збірник нормативних актів. 2000. Київ : Юрінком Інтер.

42. Про Концепцію організації підготовки магістрів в Україні: наказ MOH № 99 від 10.02 .2010 p. URL: http://osvita.ua/legislation/ Vishya_osvita/7094/ (дата звернення 29.01.2016).

43. Галімов Ю. А. Комплексний підхід до забезпечення якості підготовки фахівців. Вісник Національної академії Державної прикордонної служби України. 2011. URL: www.irbis-nbuv.gov.ua/ (дата звернення 09.04.2018).

44. Лапінський В.В., Пилипчук А.Ю., Шишкіна М.П. Засоби інформаційно-комунікаційних технологій єдиного інформаційного простору системи освіти України : монографія. Київ : Педагогічна думка. 2010.

45. Івашкевич Е.3. Комплексний підхід до визначення структури соціального інтелекту педагога. Проблеми сучасної психології. 2016. Вип. 34. URL: ttp://problemps.kpnu.edu.ua/en/ (дата звернення 04.04.2018).

\section{Information about the author: Batsurovska I. V.,} Doctor of Pedagogical Sciences, Associate Professor, Associate Professor at the Department of Electric Power, Electrical Engineering and Electrical Mechanics Mykolayiv National Agrarian University 9, Heorhiia Honhadze str., Mykolayiv, 54000, Ukraine 